\title{
Optimization of Metabolite Extraction Protocols for Untargeted Metabolite Profiling of Mycoparasitic Scytalidium parasiticum using LC-TOF-MS
}

\author{
(Pengoptimuman Protokol Pengekstrakan Metabolit Tak Bertumpu bagi Profil Metabolit daripada
} Mikoparasit Scytalidium parasiticum Menggunakan LC-TOF-MS)

\author{
CHOON KiAT LIM*, RAFIDAH AHMAD, NuRUl FADHILAH MARZUKI, Yit KHENG GOH, \\ KAMALRUL AZLAN AZIZAN, YOU KENG GOH \& KAH JOO GOH
}

\begin{abstract}
Basal stem rot disease of oil palm caused by Ganoderma boninense is one of the most devastating diseases in oil palm plantation resulting in low yield, loss of palm stands and shorter replanting cycle. To-date, there is no effective treatment for Ganoderma infected palms. Control measures, either chemical or cultural approaches, show varying degrees of effectiveness. The application of biological control agents which is environmental-friendly could be an attractive solution to overcome the problem. Earlier, we had isolated a mycoparasite, Scytalidium parasiticum, from the basidiomata of Ganoderma boninense. In vitro assay and nursery experiment showed that this fungus could suppress Ganoderma infection and reduce disease severity. However, metabolites which might contribute to the antagonistic or mycoparasitic effect remain unknown. In the current study, optimization of fungal sample processing, extraction, and analytical procedures were conducted to obtain metabolites from the maize substrate colonized by mycoparasitic ascomycetous Scytalidium parasiticum. This technique capable of producing sexual spores in sac-like organs. Untargeted metabolomics profiling was carried out by using Liquid Chromatography Time of Flight Mass Spectrometry (LC-ToF-MS). We found that S. parasiticum in both liquid-and solid-state cultivation gave higher metabolite when extracted with $60 \%$ methanol with $1 \%$ formic acid in combination with homogenisation methods such as ultrasonication and grinding. The findings from this study are useful for optimisation of metabolite extraction from other fungi-Ganoderma-plant interactions.
\end{abstract}

Keywords: Biocontrol agent; Ganoderma boninense; LC-ToF-MS; metabolomics; oil palm

\section{ABSTRAK}

Penyakit busuk pangkal batang bagi pokok kelapa sawit yang disebabkan oleh Ganoderma boninense adalah salah satu penyakit yang paling serius di ladang sawit yang mengakibatkan hasil yang rendah, kekurangan pokok sawit yang produktif dan kitaran penanaman semula yang lebih singkat. Sehingga kini, tiada rawatan berkesan untuk pokok sawit yang dijangkiti Ganoderma. Langkah-langkah kawalan, sama ada pendekatan kimia dan teknik pengkulturan, menunjukkan tahap keberkesanan yang berlainan. Penggunaan agen kawalan biologi yang mesra alam boleh menjadi langkah alternatif yang terbaik dalam menangani masalah ini. Scytalidium parasiticum telah dipencilkan daripada basiodamata G. boninense. Kajian in vitro dan nurseri telah menunjukkan bahawa kulat ini boleh merencatkan jangkitan Ganoderma dan mengurangkan kesan yang lebih parah terhadap penyakit ini. Walau bagaimanapun, metabolit yang mungkin menyumbang kepada kesan antagonistik atau mikoparasit masih tidak diketahui. Dalam kajian ini, pengoptimuman pemprosesan sampel, pengekstrakan dan analisis dilakukan untuk mendapatkan metabolit daripada mikoparasit askomise S. parasiticum yang dikultur dengan substrat jagung. Teknik ini mampu menghasilkan spora seksual dalam organ seperti sac. Pemprofilan metabolomik tidak bertumpu dilakukan dengan Kromatografi Cecair Ion Terbang Spektrometri Jisim (LC-ToF-MS). Kami mendapati bahawa S. parasiticum yang dikultur dalam media cecair dan dalam keadaan pepejal memberikan jumlah metabolit lebih tinggi apabila diekstrak dengan $60 \%$ metanol dan $1 \%$ asid formik dengan kombinasi kaedah penghomogen seperti ultrasonikasi dan pengisaran. Keputusan kajian ini adalah berguna untuk mengoptimumkan penghasilan metabolit daripada ekstrak interaksi kulat-Ganoderma-sawit.

Kata kunci: Agen biokawalan; Ganoderma boninense; kelapa sawit; LC-ToF-MS; metabolomik

\section{INTRODUCTION}

Basidiomycetous Ganoderma boninense Pat., the main causal agent of white rot disease or also known as basal stem rot (BSR) and upper stem rot (USR) diseases in oil palm (Elaeis guineensis Jacq.), together with a few other Ganoderma species, were reported to harbour a series of fungicolous fungi (Agustini et al. 2014; Chaverri et al. 2015; Gams et al. 2004; Helfer 1991; Kang et al. 2011; Põldmaa et al. 1999; Rogerson \& Samuels 1993). In a few recent studies related to fungiculous fungi associated with G. boninense, Cladobotryum semicirculare G.R.W.Arnold, R. Kirschner \& Chee J. Chen initially isolated from $G$. 
tsugae Murrill (Kirschner et al. 2007), was also reported from G. boninense (Marzuki et al. 2015); and Scytalidium parasiticum Y-Kheng Goh, Goh, Y.K. Goh, K.J. Goh was isolated from $G$. boninense (Goh et al. 2015).

Secondary metabolites, namely yellow pigments from Scytalidium ganodermophthorum suppressed the growth of G. lucidum and were postulated to assist in Ganoderma host parasitism as well (Kang et al. 2010; Oh et al. 1998). Kang et al. (2014) attempted to extract the antifungal metabolites from $S$. ganodermophthorum with methanol and ethyl acetate; both methanol and ethyl acetate extracts illustrated growth inhibition in Phytophothora capsici Leonian and other fungal pathogens at the concentration of $100 \mathrm{ppm}$ or higher. In vitro Ganoderma pathogenicity tests showed the capability of $S$. ganodermophthorum in reducing the survival of G. lingzhi only, whereas, the newly described potential necrotrophic mycoparasitic $S$. parasiticum was able to reduce the survival of $G$. boninense and other tested Ganoderma species (Goh et al. 2016). Necrotrophic mycoparasites normally kill the host cells prior to occupying them and followed by extracting nutrients from the dead cells (Boosalis 1964). In a preliminary experiment conducted in $2014, S$. parasiticum-maize methanol extracts were found to be inhibitory to the growth of $G$. boninense, on contrary; there was no inhibition in when $S$. parasiticum-maize ethyl acetate was used (unpublished data). The major functions and identity of dark yellowish and green fluorescent pigments produced by $S$. parasiticum inoculated on maize or during the interactions with Ganoderma were still unknown. To the best of our knowledge, the information related to the metabolomics study on fungicolous or mycoparasitic fungi in close association with Ganoderma boninense is limited especially since Scytalidium parasiticum is a newly identified and described parasite of G. boninense. In this study, a series of metabolite extraction protocols for $S$. parasiticum were performed and evaluated prior to LCToF-MS analyses. These protocols were based on: Choice of extraction solvents - $60 \%$ methanol amended with $1 \%$ formic acid, $100 \%$ methanol, $100 \%$ acetonitrile, and water only; state (liquid/solid state) of fungus cultivation; and homogenisation methods (grinding vs non-grinding and ultrasonication vs non-sonication). Optimized protocols will be useful for future metabolomics studies on bitrophic Scytalidium-Ganoderma or Scytalidium-plant, and tritrophic Scytalidium-Ganoderma-plant interactions, as well as screening for potential antifungal compounds to manage $G$. boninense.

\section{MATERIALS AND METHODS}

\section{CHEMICALS}

Methanol and acetonitrile were purchased from Merck, Germany. Formic acid and caffeic acid for LC-ToF-MS analyses were purchased from Sigma-Aldrich, USA. All solvents used were MS grade.

\section{FUNGAL ISOLATE AND CULTURE CONDITIONS}

Ascomycetous, potentially necrotrophic mycoparasitic Scytalidium parasiticum AAX0113 was maintained on malt extract agar (MEA; Difco) and incubated at $24^{\circ} \mathrm{C}$ in the dark for 7 days prior to transferring the mycelial plugs $\left(1 \mathrm{~cm}^{2}\right.$ in diameter) onto sterilized maize (dry kernels) and incubated for an additional 14 days. Solid-state cultivation: Fourteen-day-old $S$. parasiticum-inoculated sterilized maize was prepared for metabolites extraction in most of the experiments, unless otherwise specified. Liquidstate cultivation: Maize was blended into powder using a Waring ${ }^{\circledR}$ laboratory blender and approximately $75 \mathrm{~g}$ of maize powder was added into $500 \mathrm{~mL}$ of double distilled water $\left(\mathrm{ddH}_{2} \mathrm{O}\right)$ to produce maize extract broth (MaEB). Maize sterilization was carried out according to Goh et al. (2016) prior to inoculating with $S$. parasiticum.

\section{FUNGAL METABOLITES EXTRACTION AND OPTIMIZATION}

Fungal metabolites extraction with samples from solid-state cultivation: Twenty $\mathrm{mL} 60 \%$ cold methanol supplemented with $1 \%$ formic acid was added into 20 g maize inoculated with Scytalidium parasiticum or 20 $\mathrm{g}$ un-inoculated maize and the mixtures were vortexed vigorously for $30 \mathrm{~s}$, followed by frozen in liquid nitrogen for $5 \mathrm{~min}$. The samples were then thawed on ice for 10 min. Methanol extracts were transferred to new $1.5 \mathrm{~mL}$ Eppendorf tubes and centrifuged at 10,000 rpm for 10 min at $4^{\circ} \mathrm{C}$. The supernatant was then transferred to new cold tube and the precipitated pellet was re-extracted with $60 \%$ cold methanol amended with $1 \%$ formic acid. The extracts were then vortexed for $30 \mathrm{~s}$ and followed by centrifugation at $10,000 \mathrm{rpm}$ for $10 \mathrm{~min}$ at $4^{\circ} \mathrm{C}$. Supernatants from first and second extractions were combined and concentrated for 4 to $6 \mathrm{~h}$ using vacuum concentrator (Eppendorf Concentrator plus). The samples were stored at $-80^{\circ} \mathrm{C}$ prior to metabolomics analysis.

Fungal metabolites extraction with samples from liquid-state cultivation: MaEB inoculated with $S$. parasiticum or the non-inoculated MaEB were incubated at $24^{\circ} \mathrm{C}$ on a rotary shaker at $150 \mathrm{rpm}$ for 2 weeks. Both the inoculated and non-inoculated MaEB were centrifuged at $7000 \mathrm{rpm}$ for $15 \mathrm{~min}$ at $4^{\circ} \mathrm{C}$. The extracts were filter-sterilized with $0.45 \mu \mathrm{m}$ filter (Whatman). Three hundred $\mu \mathrm{L}$ of the extracts were transferred to $900 \mu \mathrm{L} 60 \%$ cold methanol with $1 \%$ formic acid and the mixtures were vortexed vigorously for $3 \mathrm{~s}$. The samples were then concentrated for 4 to $6 \mathrm{~h}$ using vacuum concentrator and stored at $-80^{\circ} \mathrm{C}$ prior to metabolomics analysis.

Two other solvents, namely $100 \%$ acetonitrile and water were selected for fungal metabolites extraction with samples from both solid- and liquid-state cultivations. These two solvents were compared to $60 \%$ methanol supplemented with $1 \%$ formic acid. 
OPTIMIZATION 1: WITH AND WITHOUT VACUUM CONCENTRATION

During fungal metabolites extraction, once the supernatants from the first and second extractions were combined, the combined supernatants were concentrated in vacuum concentrator for 4 to $6 \mathrm{~h}$. The supernatants without vacuum concentration were used as the control. The effects of vacuum concentration on the extracted supernatants were evaluated. There was no difference in the number of metabolite features (21 peaks) recorded for both treatments - with and without concentration (Data not shown).

\section{OPTIMIZATION 2: GRINDING VS NON-GRINDING}

Scytalidium parasiticum-inoculated and non-inoculated maize were subjected to grinding Waring ${ }^{\circledR}$ blender prior to solvent extraction. The non-grounded samples were used for comparison as well.

\section{OPTIMIZATION 3: SONICATION VS NON-SONICATION}

Scytalidium parasiticum-inoculated and non-inoculated maize were subjected to sonication in an ice bath with a sonic dismembrator (Fisher Scientific, FB120) fitted with a Model CL-18 probe at $65 \%$ power and $30 \%$ amplitude with $15 \mathrm{~s}$ pulses. The sonication process was then repeated 4 times after a one-minute pause in between each cycle. The non-sonicated samples were used as the control.

\section{LC-TOF-MS ANALYSES}

Fungal metabolites extracted from $S$. parasiticuminoculated and non-inoculated MaEB (liquid-state cultivation) were selected for optimizing the LC-MS protocols, namely flow rates, gradients, oven temperatures and columns. Mobile phases contained water $+0.1 \%$ formic acid (A) and $100 \%$ acetonitrile (B). The column oven was operated at $35^{\circ} \mathrm{C}$. About $1 \mu \mathrm{L}$ of sample was injected onto a Thermo Scientific C18 column (AcclaimTM Polar Advantage II, $3 \times 150 \mathrm{~mm}, 3 \mu \mathrm{m}$ particle size) and subjected to the following gradient using an UltiMate 3000 UHPLC system (Dionex) HPLC system: Protocol $1-0.4 \mathrm{~mL} /$ min flow rate, $0-3 \mathrm{~min}-5 \% \mathrm{~B}, 3-10 \mathrm{~min}-80 \% \mathrm{~B}, 10-15$ $\mathrm{min}-80 \% \mathrm{~B}$ and $15-22 \mathrm{~min}-5 \% \mathrm{~B}$; Protocol $2-0.3 \mathrm{~mL} /$ min flow rate, 0 min $-2 \% \mathrm{~B}, 0-22 \mathrm{~min}-28 \% \mathrm{~B}, 22-22.5$ $\min -40 \% \mathrm{~B}, 23-25 \mathrm{~min}-95 \% \mathrm{~B}$, and 25-30 $\min -5 \% \mathrm{~B}$; Protocol 3 - similar to Protocol 2, except X-bridge HILIC column $(3.5 \mu \mathrm{m}$ particle size, $150 \times 4.6 \mathrm{~mm})$ was used; and Protocol $4-0.3 \mathrm{~mL} / \mathrm{min}$ flow rate, $0-1 \mathrm{~min}-0 \% \mathrm{~B}, 1-5$ $\min -20 \% \mathrm{~B}, 5-20 \mathrm{~min}-100 \% \mathrm{~B}, 20-25 \mathrm{~min}-100 \% \mathrm{~B}$, 25-26 min $-10 \% \mathrm{~B}$, and 26-35 min - 0\% B. The gradient parameter in Protocol 1 was based on Bruker's Gradient System Default method. The latter protocol was improvised from the default protocol. Sodium formate solution was injected as external calibration standard in the void volume of each chromatographic run.

High resolution mass spectrometry (MicroTOF QIII Bruker Daltonic, Germany) was carried out using ESI source in positive and negative ion modes, with the following settings: -capillary voltage: $4500 \mathrm{~V}$; nebulizer pressure: 1.2 bar; drying gas: $8 \mathrm{~L} / \mathrm{min}$ at $200^{\circ} \mathrm{C}$. The mass range was at $50-1000 \mathrm{~m} / \mathrm{z}$. The MS data were processed through Data Analysis 4.1 software (Bruker Daltonics, Bremen, Germany). Relevant features were extracted using the Find Molecular Features algorithm and Dissect algorithm for deconvolution. The dissect algorithm for deconvolution combines all ions with a similar chromatogram profiles to one compound. Number of peaks and elution patterns were assessed from chromatograms generated. The proposed compounds were determined by online databases of ChEBI (Chemical Entities of Biological Interest), KEGG (Kyoto Encyclopedia of Genes and Genomes) and METLIN using the CompoundCrawler function in DataAnalysis. Metfrag would be used if no match was found from databases above.

\section{RESULTS AND DISCUSSION}

\section{OPTIMIZATION OF LC-TOF-MS PROTOCOLS - FLOW RATES, GRADIENTS, OVEN TEMPERATURES, AND COLUMNS}

Four separate protocols for LC-ToF-MS were assessed and optimized using metabolites extracted from maize inoculated with and without $S$. parasiticum through solid- and liquid-state cultivation. However, only results on the number of peaks based on fungal metabolites extracted using liquid-state cultivation were summarized in Table 1. The metabolites were extracted using $60 \%$ cold methanol supplemented with $1 \%$ formic acid. Based on the fungal metabolites extracted from liquidstate cultivation, protocol 2 gave the highest number of peaks at 24 , followed by protocol 4 with 22 peaks, and lastly protocols 1 and 3 (less than 15) (Table 1). Protocol 2 produced a better chromatogram and more distinct basement compared to protocol 4 (Data not shown). The gradient steps in protocol 2 were designed to be much shallower with a longer gradient time and a lower flow rate to maximize the chromatographic peak capacity compared to protocol 1 and protocol 4. For protocol 3, the used of more polar column, X-bridge HILIC column (3.5 $\mu \mathrm{m}$ particle size, $150 \times 4.6 \mathrm{~mm}$ ) was employed to retain more polar compounds since many studies report the success of HILIC in improving the peak shape and enhanced sensitivity with ESI-MS detection (Gray et al. 2013). However, protocol 2 still produced better results based on the number of peaks detected compared to protocol 3. The number of peaks detected were much lower in HILIC column suggesting the extracts contains less polar compounds. Therefore, protocol 2 was selected for further optimization. Among the three solvents tested, namely acetonitrile, water and cold methanol amended with formic acid, the latter solvent yielded the highest number of peaks (Figure 1). 
TABLE 1. Four different protocols of LC-MS studied and number of peaks. *Protocol

1 to 4 is referring to optimization of the LC-MS protocols, namely flow rates, gradients, oven temperatures, and columns

\begin{tabular}{cc}
\hline Protocols* & Number of peaks \\
\hline Protocol 1 & 14 \\
Protocol 2 & 24 \\
Protocol 3 & 11 \\
Protocol 4 & 22 \\
\hline
\end{tabular}

* Protocol $1-0.4 \mathrm{~mL} / \mathrm{min}$ flow rate, $0-3 \mathrm{~min}-5 \% \mathrm{~B}, 3-10 \mathrm{~min}-80 \% \mathrm{~B}, 10-15 \mathrm{~min}-80 \% \mathrm{~B}$, and $15-22 \mathrm{~min}-5 \% \mathrm{~B}$; Protocol $2-0.3 \mathrm{~mL} / \mathrm{min}$ flow rate, $0 \mathrm{~min}-2 \% \mathrm{~B}, 0-22 \mathrm{~min}-28 \% \mathrm{~B}, 22-22.5 \mathrm{~min}-40 \% \mathrm{~B}, 23-25 \mathrm{~min}-95 \% \mathrm{~B}$, and 25-30 min - 5\% B; Protocol 3 - similar to Protocol 2, except X-bridge HILIC column (3.5 $\mu \mathrm{m}$ particle size, $150 \times 4.6$ $\mathrm{mm}$ ) was used; and Protocol $4-0.3 \mathrm{~mL} / \mathrm{min}$ flow rate, $0-1 \mathrm{~min}-0 \% \mathrm{~B}, 1-5 \mathrm{~min}-20 \% \mathrm{~B}, 5-20 \mathrm{~min}-100 \% \mathrm{~B}, 20-25$ $\min -100 \% \mathrm{~B}, 25-26 \mathrm{~min}-10 \% \mathrm{~B}$, and $26-35 \min -0 \% \mathrm{~B}$

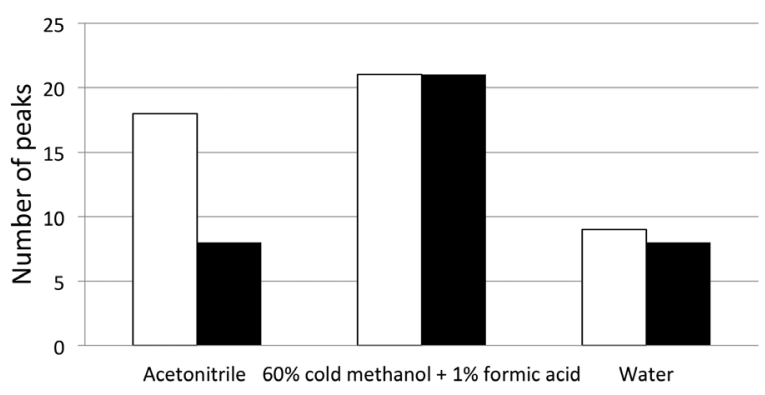

FIGURE 1. Number of peaks retrieved from liquid chromatography mass spectroscopy (LC-ToF-MS) for the samples with three different solvents. White and solid black bars refer to fungal metabolites extracted through liquid- and solid-state cultivation, respectively

\section{OPTIMIZATION OF LIQUID CHROMATOGRAPHY TANDEM MASS SPECTROSCOPY (LC-TOF-MS) - POSITIVE AND NEGATIVE POLAR}

The putative metabolites and their respective retention times and M/Z values obtained through LC-ToF-MS with positive and negative ionizations were summarized in Table 2. These metabolites were sugars, alkaloids, amino acids, sugar alcohols and flavonoids. Negative polar ionization was observed to yield three more compounds (Table 2). The use of both positive and negative ionizations covered more wide-range of metabolites than the use of single polarity. Several metabolites were observed only at positive mode and some were detected in negative mode (Lei et al. 2011). Terpenoid and flavonoids founds in this study showed higher sensitivity in the positive ionization as compared to negative mode. These compounds such as arjunone, ligustroside, quercetin 5,7,3',4'-tetramethyl ether 3-rutinoside, benzal chloride and 1-Isothiocyanato-7(methylsulfinyl)heptane were reported to have antioxidant, antifungal, anti-inflammatory and antimicrobial properties (Ferreira et al. 2010; Lim et al. 2017; Madla et al. 2012; Srivastava et al. 2001; Stupar et al. 2014).

\section{OPTIMIZATION OF THE SOLVENTS FOR METABOLITES EXTRACTION}

The effect of extraction solvents on the number of metabolites extracted from $S$. parasiticum was assessed. Fungal metabolites were initially extracted with absolute methanol, but the methanol extracts yielded fewer than
10 peaks (Data not shown). In a previous preliminary study, $S$. parasiticum-inoculate maize methanol extracts had greater growth inhibition in $G$. boninense compared to ethyl acetate extracts (Unpublished data). Therefore, methanol was selected as one of the extraction solvents. The extraction efficiency of a given solvent is evaluated by the number of peaks observed in the chromatogram. Among the three solvents tested, 60\% methanol with 1\% formic acid was the best in extracting metabolites from solid and liquid cultures of $S$. parasiticum compared to acetonitrile and water (Figures 1 \& 2).

Similarly, Madla et al. (2012) showed that methanol was the suitable solvent for metabolite extraction of white-rot Basidiomycete, Phanerochaete chrysosporium, for many advantages such as good extraction efficiency and good recovery of metabolites. Recent study showed that the methanol extract of Toona sinensis leaves exhibited the highest inhibitory activity against $G$. boninense. Methanol is capable of extracting antifungal compounds due to the presence of hydroxyl and methyl group in methanol that could bind to polar, semi-polar and non-polar metabolites (Elfirta et al. 2018). In future, fractionation of methanol extract could be performed to identify bioactive compounds of $S$. parasiticum. Based on the comparative study on different solvents, $60 \%$ methanol amended with $1 \%$ formic acid was adopted for all other optimizations. There was no difference in term of number of peaks detected for both liquid- and solid-state cultivations (Figure 3 ). 


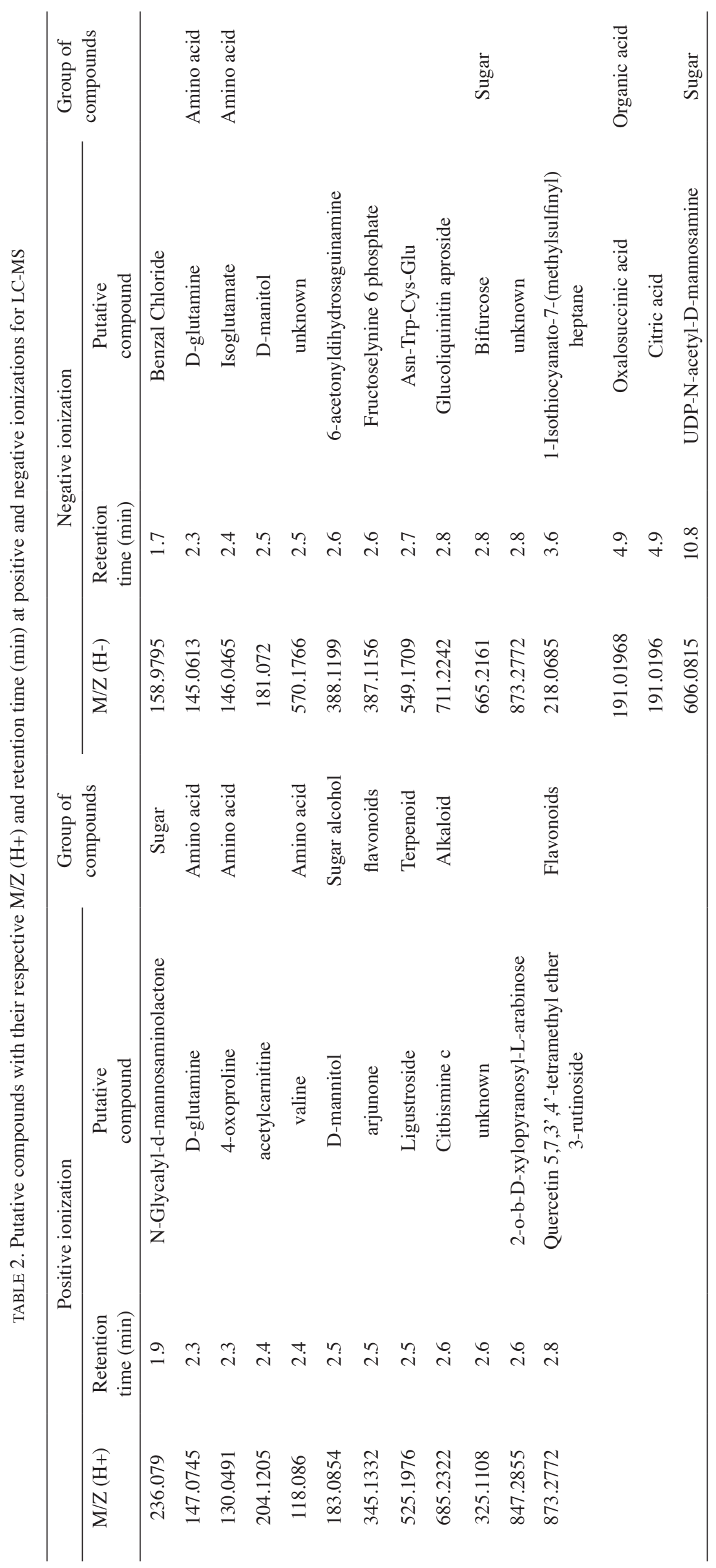




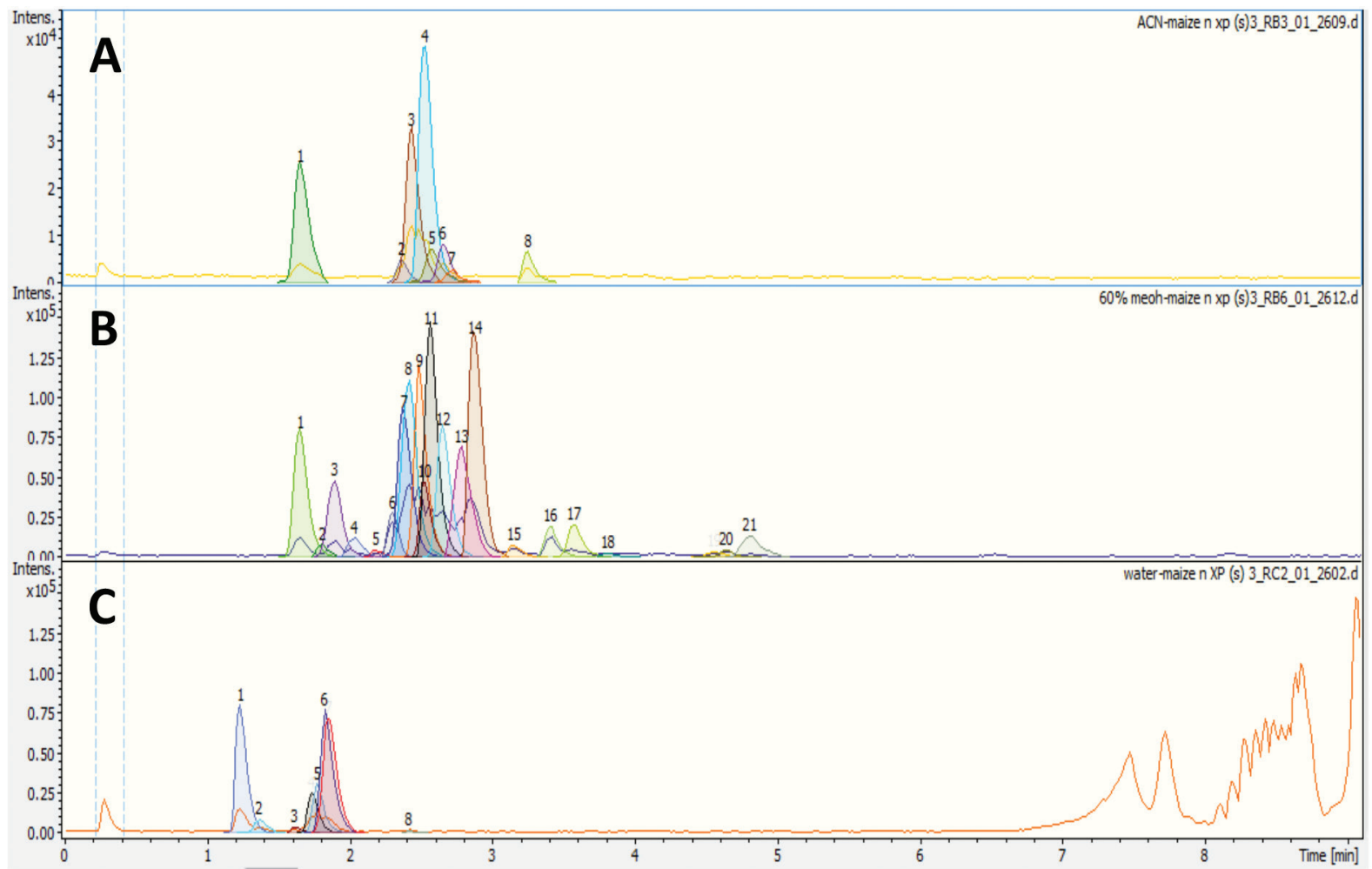

FIGURE 2. Chromatograms generated from metabolite extracts yielded from Scytalidium parasiticum-inoculated maize (solid-state cultivation) with three different solvents - acetonitrile (A), $60 \%$ methanol $+1 \%$ formic acid (B), and water (C)

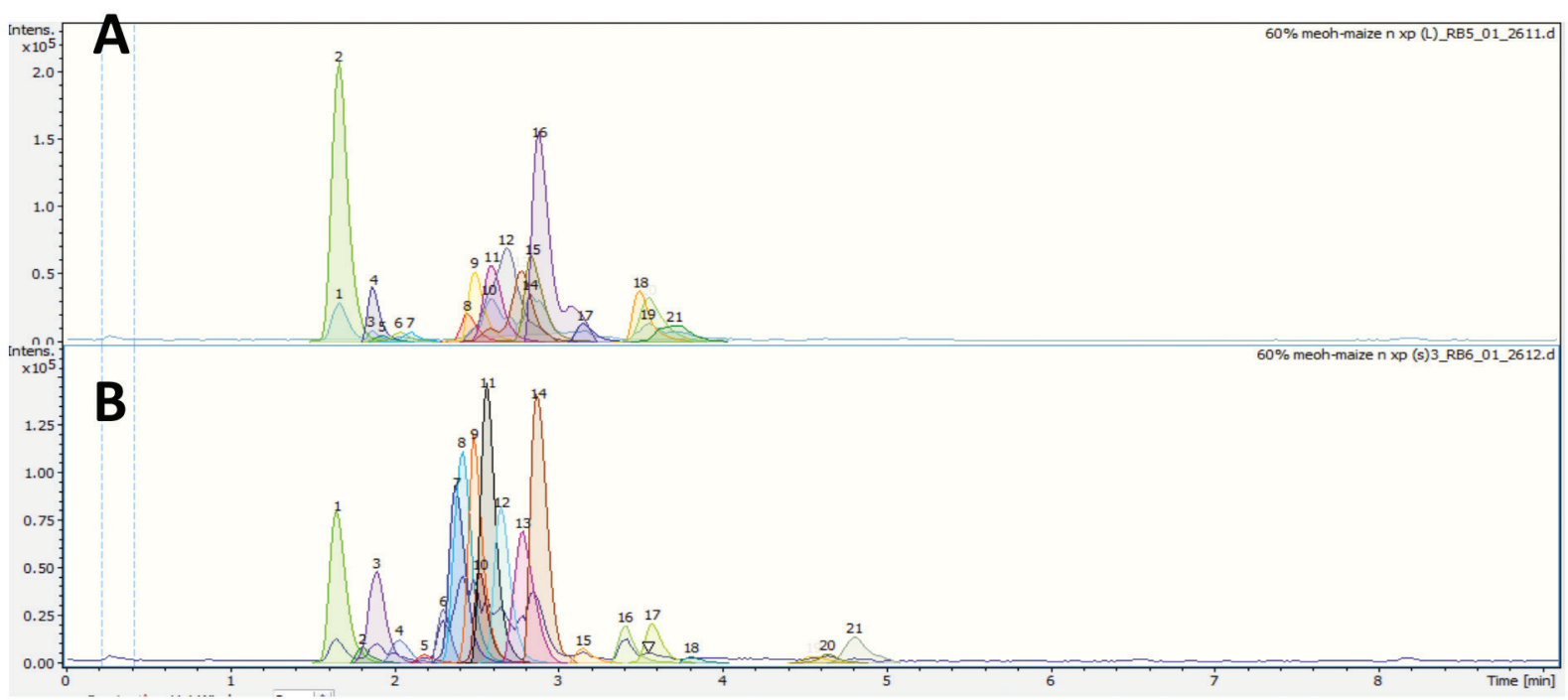

FIGURE 3. Chromatograms for metabolites extracted using $60 \%$ methanol with $1 \%$ formic acid from Scytalidium parasiticuminoculated maize through liquid- (A) and solid- (B) state cultivations

\section{OPTIMIZATION OF SAMPLES PREPARATION AND PROCESSING - WITH AND WITHOUT GRINDING AND SONICATION}

Grounded samples, namely $S$. parasiticum-inoculated and non-inoculated maize yielded the highest numbers of peaks compared to non-grinding samples (Table 3). Grinding tissues in a liquid $\mathrm{N}_{2}$-cooled mortar and pestle is a common method in breaking up tissues and cells, thus improving extraction efficacy. However, this method is laborious. In the future, homogenisation by an electric tissue homogeniser can be used considering speed and ease of extraction that this method can offer (Lin et al. 2007). Similar observations were recorded in sonicated samples (S. parasiticum-inoculated maize) with higher number of peaks compared to non-sonicated samples (Table 3). Ultrasonic-assisted extraction is a more useful approach 
TABLE 3. Sample preparations and processing methods, and number of peaks

\begin{tabular}{clc}
\hline Sample preparation and processing & \multicolumn{1}{c}{ Samples } & Number of peaks \\
\hline Grounded $*$ & Maize only \\
Non-grounded & Maize with Sp. & 33 \\
& Maize only & 27 \\
\cline { 2 - 3 } & Maize with Sp. & 17 \\
\hline Freeze-thawed** & Maize with Sp. & 21 \\
Non-freeze-thawed & Maize with Sp. & 21 \\
\hline Sonicated & Maize with Sp. & 30 \\
Non-sonicated & Maize with Sp. & 26 \\
\hline
\end{tabular}

* Grinding refers to samples were grounded in Waring ${ }^{\circledR}$ blender prior to solvent extraction

** Freeze-thawing practice refers to samples in solvent were subjected to frozen with liquid nitrogen and thawing on ice

${ }^{\ddagger}$ Maize only refers to non-inoculated maize substrates

Maize with Sp. refers to Scytalidium parasiticum-inoculated maize substrates

than conventional solvent extraction method. It had been reported to improve recovery of metabolites with lower solvent consumption and had been used for the extraction of sugars, oil and polysaccharides (Gil-Chávez et al. 2013).

\section{SAMPLES STORAGE AND DEGRADATION}

Extracted metabolites samples were stored in $-20^{\circ} \mathrm{C}$ for 2 weeks prior to metabolomics analysis with LC-ToF-MS. Degradation of the existing compounds or metabolites were observed. Once the extracts were stored in $-20^{\circ} \mathrm{C}$ for 2 weeks, there was very low number of peaks and intensity of peak recorded (Data not shown). Therefore, the extracted samples were either stored in $-80^{\circ} \mathrm{C}$ or analyzed within the first few days after metabolites extraction. It is crucial to store samples extracted in dark and at a very low temperature to avoid degradation. However, it is possible that some metabolites tend to degrade at low temperature due to oxidation (Pinu \& Villas-Boas 2017).

\section{CONCLUSION}

We found that $S$. parasiticum in both liquid- and solid- state cultivation gave higher number of peaks in chromatograms when extracted with $60 \%$ methanol with $1 \%$ formic acid in combination with homogenisation methods such as ultrasonication and grinding. Further, some putative metabolites produced by $S$. parasiticum may have antifungal and antioxidant properties that merit future investigation. Current findings will be useful for future metabolomics studies on bitrophic Scytalidium-Ganoderma or Scytalidium-plant and tritrophic Scytalidium-Ganoderma-plant interactions, as well as screening for potential antifungal compounds to manage $G$. boninense.

\section{ACKNOWLEDGEMENTS}

The authors wish to thank the Institute of Systems Biology, Universiti Kebangsaan Malaysia (INBIOSIS-UKM) for assistance in LC-ToF-MS analyses. The authors would also like to thank AAR Principals, Boustead Plantations
Berhad and Kuala Lumpur Kepong Berhad for funding this research under the grant number RB-2015-002 and for their permission to publish the data in this paper.

\section{REFERENCES}

Agustini, L., Wahyuno, D., Indrayadi, H. \& Glen, M. 2014. In vitro interaction between Phlebiopsis sp. and Ganoderma philippii isolates. Forest Pathology 44: 472-476.

Boosalis, M.G. 1964. Hyperparasitism. Annual Review of Phytopathology 2: 363-376.

Chaverri, P., Branco-Rocha, F., Jaklitsch, W., Degenkolb, T. \& Samuels, G.J. 2015. Systematics of the Trichoderma harzianum species complex including the identification of commercial biocontrol strains. Mycologia 107: 558-590.

Elfirta, R.R., Falah, S., Andrianto, D. \& Lastini, T. 2018. Identification of active compounds and antifungal activity of Toona sinensis leaves fractions against wood rot fungi. Biodiversitas 19: 1313-1318.

Ferreira, J.F.S., Luthria, D.L., Sasaki, T. \& Heyerick, A. 2010. Flavonoids from Artemisia annua L. as antioxidants and their potential synergism with Artemisinin against malaria and cancer. Molecules 15: 3135-3170.

Gams, W., Diederich, P. \& Põldmaa, K. 2004. Fungicolous fungi. In Biodiversity of Fungi: Inventory and Monitoring Methods, edited by Mueller, G.M., Bills, G.F. \& Foster, M.S. USA: Elsevier Academic Press. pp. 343-392.

Goh, Y.K., Marzuki, N.F., Goh, T.K., Tan, S.Y., Goh, Y.K. \& Goh, K.J. 2016. Mycoparasitic Scytalidium parasiticum as a potential biocontrol agent against Ganoderma boninense basal stem rot (BSR) in oil palm (Elaeis guineensis). Biocontrol Science and Technology 26: 1352-1365.

Goh, Y.K., Goh, T.K., Marzuki, N.F., Tung, H.J., Goh, Y.K. \& Goh, K.J.2015. Scytalidium parasiticum sp. nov., parasitizing on Ganoderma boninense from oil palm in Malaysia. Mycobiology 43: 107-117.

Gray, N., Heaton, J., Musenga, A., Cowan, D.A., Plumb, R.S. \& Smith, N.W. 2013. Comparison of reversed-phase and hydrophilic interaction liquid chromatography for the quantification of ephedrines using medium-resolution accurate mass spectrometry. Journal of Chromatography A 1289: 37-46.

Helfer, W. 1991. Pilze auf Pilzfruchtkorpern. Untersuchungen zur on the c Systematik und Chemie. Libri Botanici 1: 11. 
Joana Gil-Chávez, G., Villa, J.A., Fernando Ayala-Zavala, J., Basilio Heredia, J., Sepulveda, D., Yahia, E.M. \& González-Aguilar, G.A. 2013. Technologies for extraction and production of bioactive compounds to be used as nutraceuticals and food ingredients: An overview. Comprehensive Reviews in Food Science and Food Safety 12: 5-23.

Kang, H.J., Ahn, K.S., Han, C.W., Jeong, K.H., Park, S.J., Song, I.G., Yun, T. \& Min, K.B. 2014. Xylogone ganodermophthora strain with antifungal activity and composition including same for preventing plant diseases, U.S. Patent Application No. 20140220068, The United States Patent and Trademarks Office, Washington, DC, USA.

Kang, H.J., Sigler, L., Lee, J., Gibas, C.F.C., Yun, S.H. \& Lee, Y.W. 2010. Xylogone ganodermophthora sp. nov., an ascomycetous pathogen causing yellow rot on cultivated mushroom Ganoderma lucidum in Korea. Mycologia 102: 1167-1184.

Kirschner, R., Arnold, G.R.W. \& Chen, C.J. 2007. Cladobotryum semicirculare sp. nov. (Hyphomycetes) from commercially grown Ganoderma tsugae in Taiwan and other Basidiomycota in Cuba. Sydowia 59: 114-124.

Lei,Z.,Huhman, D.V. \& Sumner, L.W. 2011. Mass spectrometry strategies in metabolomics. Journal of Biological Chemistry 286(29): 25435-25442.

Lim, H., Kim, H.J., Jeong, H. \& Park, H.R. 2017. Antiinflammatory effects of 1-isothiocyanato-7-(methylsulfonyl) heptane by suppressing the NFx-B signalling pathway. European Journal of Inflammation 15: 57-65.

Lin, C.Y., Wu, H., Tjeerdema, R.S. \& Viant, M.R. 2007. Evaluation of metabolite extraction strategies from tissue samples using NMR metabolomics. Metabolomics 3: 55-67.

Madla, S., Miura, D. \& Wariishi, H. 2012. Optimization of extraction method for GC-MS based metabolomics for filamentous fungi. Microbial \& Biochemical Technology 4: 005-009.

Marzuki, N.F., Goh, Y.K., Tung, H.J., Goh, Y.K. \& Goh, K.J. 2015. Evaluation of the cultural characteristics and antagonistic activities of Cladobotryum semicirculare against Ganoderma boninense in-vitro. Journal of Oil Palm Research 27: 326-338.

Oh, S.J., Chun, C.S., Lee, J.K. \& Kim, H.K. 1998. Occurrence and identification of the fungus causing yellow rot on Ganoderma lucidum. Korean Journal of Mycology 26: 31-38.
Pinu, F.R. \& Villas-Boas, S.G. 2017. Extracellular microbial metabolomics: The state of the art. Metabolites 7: 1-15.

Põldmaa, K., Larsson, E. \& Kõljalg, U. 1999. Phylogenetic relationships in Hypomyces and allied genera, with emphasis on species growing on wood-decaying homobasidiomycetes. Canadian Journal of Botany 77: 1756-1768.

Rogerson, C.T. \& Samuels, G.J. 1993. Polyporicolous species of Hypomyces. Mycologia 85: 231-272.

Srivastava, S.K., Srivastava, S.D. \& Chouksey, B.K. 2001. New antifungal constituents from Terminalia alata. Fitoterapia 72: 106-112.

Stupar, M., Grbić, M.Lj., Džamić, A., Unković, N., Ristić, M., Jelikić, A. \& Vukojević, J. 2014. Antifungal activity of selected essential oils and biocide benzalkonium chloride against the fungi isolated from cultural heritage objects. South African Journal of Botany 93: 118-124.

Choon Kiat Lim*, Nurul Fadhilah Marzuki, Yit Kheng Goh, You Keng Goh \& Kah Joo Goh

Advanced Agriecological Research Sdn Bhd

No. 11 Jalan Teknologi 3/6, Taman Sains Selangor 1

Kota Damansara

47810 Petaling Jaya, Selangor Darul Ehsan Malaysia

Rafidah Ahmad \& Kamalrul Azlan Azizan

Metabolomics Research Laboratory

Institute of Systems Biology (INBIOSIS)

Universiti Kebangsaan Malaysia

43600, UKM Bangi, Selangor Darul Ehsan

Malaysia

*Corresponding author; email: limck@aarsb.com.my

Received: 30 May 2018

Accepted: 18 September 2018 